\section{Diet of Walkingsticks on Sandhill Rangeland in Colorado ${ }^{1}$}

\section{DARRELL N. UECKERT ${ }^{2}$ AND RICHARD M. HANSEN}

Graduate Research Fellow and Professor of Range Science, Range Science Department, Colorado State University, Fort Collins.

\section{Highlight}

The seasonal dry-weight composition of the diet of walkingstick insects collected on sandhill rangeland in northeastern Colorado was determined by microscopic examination of crop contents. The walkingstick was found to be monophagous and highly selective in its feeding habits. Slimleaf scurfpea comprised essentially $100 \%$ of its seasonal diet. Preference indices were calculated from herbage availability data. The frequency of plants in the habitat and the frequency of plants in the diet of the walkingsticks were not correlated. Walkingsticks may compete with cattle for high-protein forage.

Insects are often referred to as minor biotic factors influencing forage supply and plant composition in grassland ecosystems. To a certain extent insects cause some damage to plants of every terrestrial community, either directly by feeding, or indirectly as vectors of disease organisms (Oosting, 1956). A few instances of insects affecting plant composition and succession have been reported (Dibble, 1940; Allred, 1941; Humphrey, 1962); however, plant ecologists do not

\footnotetext{
${ }^{1}$ Received April 2, 1971.
}

2 Present address is Assistant Professor of Range Management, Range and Wildlife Management Department, Texas Tech University, Lubbock, Texas 79409. assign an important role to the insect fauna that are associated with vegetation. Workers in biological control have shown that certain insects have a capacity to greatly reduce the abundance of certain plants and obviously they may be potent factors in influencing plant composition in their native habitats (National Academy of Sciences, 1969).

The evaluation of forage consumption by insects is complicated by many factors, including population densities, species diversity, and feeding habits. A complete understanding of dietary competition between herbivores and of energy flow and nutrient cycling in grassland ecosystems depends upon an exact knowledge of food habits and preferences of individual species.

The purpose of this study was to determine the food habits and feeding preferences of the walkingstick, Diapheromera velii (Orthoptera: Phasmidae), (Fig. 1) on sandhill rangeland in northeastern Colorado.

\section{Methods and Materials}

The study area was a 40 ha pasture on the Eastern Colorado Range Station, located $27 \mathrm{~km}$ north of Akron, in Washington County, Colorado. The pasture had been lightly grazed by cattle ( 4 ha/steer) during the 5 summer months for 13 years prior to this study. The climate of the area is semiarid with an average annual precipitation of about $38 \mathrm{~cm}$, most of which comes as rain during the growing season. The frost-free season is from May until early October. The study was restricted to the "deep sand" range site where soil textures are sandy loam and loamy sand. The topography is dune type with no definite drainage patterns.

The study area is in a BoutelouaCalamovilfa-Stipa-Artemisia association in the mixed-grass prairie in which grasses make up about $80 \%$ of the total dry weight of aboveground vegetation, and forbs about $6 \%$. The vegetation on the study 


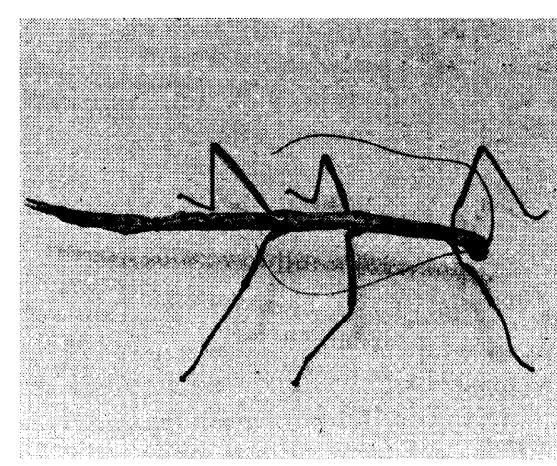

Fic. 1. Walkingstick insect. This insect feeds almost exclusively on slimleaf scurfpea in northeastern Colorado.

area has been described by Ueckert (1969).

Forage availability was assumed to be equivalent to the proportion of a particular species of plant in the standing crop of plant biomass. The dry weight of litter and of the live, aboveground parts of individual plant species was estimated on June 13, July 23, and September 4 on 100 permanently marked $30.5 \times 50 \mathrm{~cm}$ quadrats by a modification of Pechanec and Pickford's (1937) weight-estimate method.

The frequency of all plant species on the study area was recorded for 1000 quadrats on July $1-3$ by a "nested quadrat" technique (Hyder et al., 1965). The frequency for blue grama (Bouteloua gracilis) was recorded on a $5 \times 5 \mathrm{~cm}$ quadrat and a $40 \times 40 \mathrm{~cm}$ quadrat was used for all other species. The phenological stage and condition of most plant species were recorded at biweekly intervals throughout the growing season.

An attempt was made to collect at least 50 walkingstick specimens at biweekly intervals during the 1968 growing season. Specimens were captured with sweep nets or by hand as randomly as possible from the study area. Specimens were killed immediately in 95\% ethanol and stored in the ethanol until laboratory work was initiated. Several reference specimens wcre saved for identification.

In the laboratory, a microscope slide was prepared from the crop contents of each walkingstick, and

Table 1. Mean dry weight $(\%)$ of food items in the seasonal diet of walkingsticks on sandhill rangeland in northeastern Colorado.

\begin{tabular}{|c|c|c|c|c|c|c|}
\hline \multirow[b]{2}{*}{ Foods } & \multicolumn{5}{|c|}{ Date } & \multirow{2}{*}{$\begin{array}{c}\text { Mean } \\
\text { annual } \\
\text { diet }\end{array}$} \\
\hline & July 15 & July 26 & Aug. 15 & Sept. 5 & Sept. 18 & \\
\hline Sample size & 50 & 50 & 15 & 18 & 4 & 137 \\
\hline \multicolumn{7}{|l|}{ Grasses } \\
\hline Prairie sandreed & 0.4 & 0.25 & & & & $\mathrm{t}$ \\
\hline Needleandthread & $t^{1}$ & & & & & $\mathrm{t}$ \\
\hline Unknown grass & $\mathrm{t}$ & $\mathrm{t}$ & & & & $\mathrm{t}$ \\
\hline \multicolumn{7}{|l|}{ Forbs } \\
\hline Annual wildbuckwheat & & 0.25 & & & & $\mathrm{t}$ \\
\hline Slimleaf scurfpea & 99.6 & 99.5 & 100 & 100 & 100 & 99.9 \\
\hline
\end{tabular}

${ }^{1}$ Less than $0.25 \%$.

the composition of diets was estimated by microscopically examining the slides as described by Ueckert (1968). Plant tissues on slides were identified from reference tissue of identified plants. Ten fields per slide were examined and percent frequency was calculated for each food item present. Frequencies were converted to relative density as outlined by Ueckert (1968). Relative density has been shown by Sparks and Malechek (1968) to have a 1:1 ratio to the relative amount (dry-weight basis) of each food item in the diet. Relative density was used as an estimate of the dry-weight composition of each species in the diet. A mean diet was calculated for each date that walkingsticks were present and for the entire season.

Preference indices were calculated for all major foods in the diet of the walkingsticks on each collection date. The percent dry weight of the plant in the diet was divided by the percent dry weight of the plant in the standing crop of live, aboveground vegetation. Preference indices were used in conjunction with plant phenology and condition data to determine if the diets of walkingsticks change due to changes in plant conditions.

A correlation coefficient was calculated between the percent frequency of the plant species on the study area and the percent frequency of the plant species in the diet of walkingsticks to determine the degree to which their diet is influenced by plant frequency.

\section{Results and Discussion}

Walkingsticks wcre collected from mid-July through mid-September of 1968. These insects were most abundant in July and were extremely rare by mid-September. The diets of 137 specimens were determined. Five different foods were eaten by the walkingsticks and the mean number of different foods/insect crop ranged from $1.0 \pm$ 0.0 to $1.12 \pm 0.30$ (95\% confidence intervals) on different dates. The walkingstick is essentially monophagous and is highly selective in its feeding habits. Slimleaf scurfpea (Psoralea tenuiflora) was the major food of the walkingstick and comprised essentially $100 \%$ of its diet on all dates during this study. Prairie sandreed (Calamovilfa longifolia), needleandthread (Stipa comata), annual wildbuckwheat (Eriogonum annum), and an unidentified grass were eaten in trace amounts during July (Table 1).

Slimleaf scurfpea was highly preferred throughout the life cycle of the walkingstick and was the only food taken in proportions greater than its relative availability. Slimleaf scurfpea made up about $0.7 \%$ of the total dry weight of aboveground vegetation in July. This figure decreased to $0.4 \%$ in August and to $0.1 \%$ in September, due to natural mortality, dry weather, and grazing by herbivores. Preference indices for scurfpea were lowest (142) during July while it was succulent and flowering and highest $(1,000)$ during Sep- 
Table 2. Preference indices for major foods in the seasonal diet of walkingsticks on sandhill rangeland in northeastern Colorado.

\begin{tabular}{lccccc}
\hline \multicolumn{1}{c}{ Foods } & July 15 & July 26 & Aug. 15 & Sept. 5 & Sept. 18 \\
\hline Prairie sandreed & 0.02 & 0.01 & & & \\
Annual wildbuckwheat & & 0.8 & & & \\
Slimleaf scurfpea & 142.3 & 142.1 & 250.0 & $1,000.0$ & $1,000.0$ \\
\hline
\end{tabular}

tember when it was wilted and becoming dormant (Table 2). The increasing preference indices for slimleaf scurfpea as the season progressed was apparently a function of the decreasing availability of this plant, rather than of increasing consumption of the plant by walkingsticks. Heavy insect damage to slimleaf scurfpea was recorded in late July, thus the walkingstick may contribute to the decreasing availability of its host plant. Preference indices for prairie sandreed were very low due to its high availability $(20 \%$ of total standing crop) and to the fact that only small amounts were eaten. Annual wildbuckwheat was eaten in quantities almost proportional to its relative availability; however, it only comprised about $0.3 \%$ of the total standing crop of herbage.

A non-selective feeder could be expected to eat foods exactly in proportion to the frequency with which they were encountered, and consequently, $100 \%$ of the variability in its diet would be associated with plant frequency. The correlation between the frequency of plants in the habitat and the frequency of plants in the diet of the walkingsticks was not significant. Slimleaf scurfpea occurred in $99 \%$ of the microscope fields examined on slides prepared from crop samples; however, it occurred only in $5.1 \%$ of the frequency plots on the study area. Thus, the walkingstick fed upon slimleaf scurfpea almost 20 times more than a non-selective herbivore would.

Prairie sandreed occurred in 1.2\% of the microscope fields examined and in $70.3 \%$ of the frequency plots on the study area while needleandthread occurred in $0.07 \%$ of the microscope fields and in $60.9 \%$ of the frequency plots. Frequency values in microscope fields and in frequency plots on the study area were $0.36 \%$ and $0.9 \%$, respectively for annual wildbuckwheat. Thus, the walkingstick fed upon prairie sandreed and needleandthread much less often than a non-selective feeder would be expected to. Consumption of annual wildbuckwheat was considerably greater in relation to the frequency with which it was encountered.

The feeding behavior of walkingsticks is probably influenced significantly by their behavioral patterns. Gangwere (1961) reported that the Michigan phasmid (Diapheromera femorata) has arboreal habits due to negative geotaxis and feeds largely upon the leaves of oak trees (Quercus velutina); however, these phasmids fed upon Rubus when they fell to the ground. Nymphs of $D$. femorata were reported to have feeding habits unlike older nymphs and adults since they lacked negative geotaxis and occurred nearer to the ground where available foods are quite different. Thus the presence of grasses and annual wildbuckwheat in the diet of walkingsticks in July in this study may have been due to the presence of early instar nymphs in the samples; however, sample sizes were much larger during July than later in the season.

In a ten-year study of cattle diets at Eastern Colorado Range Station, Dahl $^{3}$ found that slimleaf scurfpea was not eaten by cattle in any season. However, this plant may provide an important source of protein for livestock during the autumn under certain situations. Bement (1970) reported that steers on the shortgrass prairie sought out this legume during late September

${ }^{3}$ Unpublished data. and that steers receiving no supplements but feeding on slimleaf scurfpea had a higher rate of gain and higher dry-matter conversion rate than steers receiving $1.2 \mathrm{lb}$./head/ day of cottonseed cake. Thus, in some instances, walkingsticks may compete with cattle for high-protcin forage.

\section{Literature Cited}

Allred, B. W. 1941. Grasshoppers and their effect on sagebrush on the Little Powder River in Wyoming and Montana. Ecology 22:387-392.

Bement, R. E. 1970. Fall gains of steers fed cottonseed cake on shortgrass range. J. Range Manage. 23: 199-201.

Dibble, C. B. 1940. Grasshoppers, a factor in soil erosion in Michigan. J. Econ. Entomol. 33:498-499.

GangWERE, S. 1961. A monograph on food selection in Orthoptera. Trans. Amer. Entomol. Soc. 87:67230.

Humphrey, R. R. 1962 . Range Ecology. The Ronald Press Co., New York. $234 \mathrm{p}$.

Hyder, D. N., R. E. Bement, E. E. Remmenga, AND C. Terwilliger, JR. 1965. Frequency sampling of blue grama range. J. Range Manage. 18: 90-94.

National Academy of Sciences, Committee on Plant and Animal Pests, SUbCOMMITTEE ON WEEDS. 1969. Principles of plant and animal pest control. Vol. 2. Weed Control. National Academy of Sciences, Washington, D. C. $471 \mathrm{p}$.

Oosting, H. J. 1956. The Study of Plant Communities. W. H. Freeman \& Co., San Francisco. 440 p.

Peghanec, J. F., and G. D. Pickford. 1937. A weight estimate method for the determination of range or pasture production. J. Amer. Soc. Agron. 29:894-904.

Sparks, D. R., and J. C. Malechek. 1968. Estimating percentage dry weight in diets using a microscopic technique. J. Range Manage. 21: 264-265.

UECKERT, D. N. 1968. Seasonal dry weight composition in grasshopper diets on Colorado herbland. Entomol. Soc. Amer., Ann. 61:15391544.

UECKERT, D. N. 1969. Diets of grasshoppers in northeastern Colorado. Ph.D. Dissertation. Colorado State Univ., Fort Collins, Colorado. 84 p. 